\title{
Sulphur-coated Urea as a Source of Sulphur and an Enhanced Efficiency of Nitrogen Fertilizer for Spring Wheat
}

\author{
Y.S. ShivaY*, V. Pooniya, R. Prasad, M. Pal and R. Bansal \\ Division of Agronomy, ICAR-Indian Agricultural Research Institute, New Delhi, India \\ (Received 4 September 2015; Accepted 18 November 2015; \\ Communicated by J. Kubat)
}

\begin{abstract}
Use of high analysis fertilizers such as diammonium phosphate in place of ordinary superphosphate and urea in place of ammonium sulphate over years, sulphur application to crop fields has considerably decreased, which has led to widespread sulphur deficiency in Indian soils. Hence, considering this into account a field study for two years was conducted at the research farm of ICAR-Indian Agricultural Research Institute, New Delhi to evaluate sulphur-coated urea (SCU) as a source of sulphur (S) and an enhanced efficiency of nitrogen fertilizer. Prilled urea (PU) coated with 4 to $5 \% \mathrm{~S}$ significantly increased wheat grain yield to the tune of 9.58 to $11.21 \%$ and nitrogen 19.06 to $23.94 \%$ and sulphur uptake 21.76 to $29.29 \%$ over prilled urea alone by wheat. However, net return and benefit: cost ratio was the highest and significant at $5 \% \mathrm{~S}$ coating onto PU. Five \% SCU supplied $50 \%$ of the sulphur needs of the wheat crop and enhanced nitrogen recovery efficiency by $60 \%$ and is therefore recommended as sulphur as well as enhanced efficiency of nitrogen fertilizer for wheat in Indo-Gangetic plains of India. This is an important finding considering the environmental safety by increased nitrogen recovery and also productivity in present scenario.
\end{abstract}

Keywords: economics, enhanced efficiency of nitrogen fertilizer, sulphur, sulphur-coated urea (SCU), wheat

\section{Introduction}

Sulphur-coated urea (SCU) was developed by Tennessee Valley Authority (TVA) researchers for controlled release of nitrogen and is a popular turf fertilizer in USA (Prasad et al. 1971). It is currently manufactured by a number of companies in USA, Canada, Japan and China (Trenkel 1997) using different techniques and sulphur (S) content may vary from 4 to $15 \%$ or even more. SCU has also been widely tested for rice, where nitrogen use efficiency is fairly low (Prasad 2013). In an international study conducted by the International Rice Research Institute, Philippines in Asia under International Soil Fertility and Fertilizer Evaluation for Rice (INSFER), 22-25\% less SCU was required to produce same rice yield as urea (Flinn et al. 1984). In the rice-wheat cropping system at New Delhi, SCU recorded 15.6\% increase in grain yield over urea (Prasad et al. 2013). Recently Malkouti et al. (2008) reported that in field experiments at 14 locations in Iran, SCU recorded significantly higher grain and protein yield in wheat than urea.

*Corresponding author; E-mail: ysshivay@hotmail.com 
Due to continued use of high analysis fertilizers such as diammonium phosphate in place of ordinary superphosphate and urea in place of ammonium sulfate over years, $\mathrm{S}$ application to crop fields has considerably decreased. This coupled with the introduction of high yielding hybrids and varieties of cereals and introduction of intensive cropping systems, such as, rice-wheat (Prasad 2005) has severely depleted S in soils and S deficiency in soils is reported across the world: USA (Mitchell and Mullins 1990; Dick et al. 2008), Europe (Messick 2003), Australia (McLachlan 1975; Hocking et al. 1996), Central America (Raun and Barreto 1992), China (Messick 2003), India (Biswas et al. 2004) and Pakistan (Rashid et al. 1992). The Sulphur Institute at Washington, DC has played a key role in focusing on sulfur deficiency in soils. Sources of $\mathrm{S}$ generally used for crops in India include agricultural grade commercial S, gypsum, pyrites and phospho-gypsum (Prasad 2007; Oo et al. 2007; Meena and Shivay 2010). Recently bentonite sulphur has also been introduced in India (Shivay et al. 2014). There are no sulphur deposits in India and most of the $\mathrm{S}$ needed by the fertilizer industry has to be imported, making the cost of agricultural S very high. SCU has so far not been evaluated as a source of S in addition to its capability to enhance the efficiency of applied fertilizer $\mathrm{N}$ and therefore the present study was undertaken.

\section{Materials and Methods}

\section{Coating technique}

Since sulphur-coated urea (SCU) with graded levels of sulphur coating was not available. Hence, SCU with 1, 2, 3, 4 and 5\% S coating onto prilled urea (PU) used in the present study was prepared in our own research laboratory using finely ground commercial grade S of $90 \%$ purity and a 1:1 aqueous solution of gum acacia as a sticker. Sulphur coating of PU was done in lots of $5 \mathrm{~kg}$ PU in a manual rotating seed treatment drum. Five $\mathrm{kg}$ of PU was added to the drum and then required quantity of gum acacia solution was added and the drum was rotated for 15 minutes to provide a fine coating of gum acacia on urea prills. Required amount of finely ground sulphur was then added to the drum and the contents were thoroughly mixed by rotating the drum for 15 minutes. SCU so made was then transferred to plastic trays, which were dried overnight at room temperature $\left(25 \pm 5^{\circ} \mathrm{C}\right)$ using air blowing fans. Dried SCU was then transferred to plastic bags, which were stored at room temperature. The amount of sulphur required for 1, 2, 3, 4 and 5\% coating onto $5 \mathrm{~kg}$ PU was 55.6, 111.1, 166.8, 222.4 and $278.0 \mathrm{~g}$, respectively. The gum acacia needed for making 1, 2, 3, 4 and 5\% SCU was 30, 40, 50, 60 and $70 \mathrm{~g}$, respectively. SCU was made about 3-4 days before application in the field. Coating more than $5 \% \mathrm{~S}$ onto PU using the present technique was not possible. Total cost involved (cost of sulfur + coating cost) based on prevailing prices (US $\$ \mathrm{ha}^{-1}$ ) in the Indian market in coating of urea during cropping season is given in Table $\mathrm{S} 1 *$.

\footnotetext{
*Further details about the Electronic Supplementary Material (ESM) can be found at the end of the article.
} 


\section{Description of study area}

The field experiment was conducted at the research farm of the Division of Agronomy,

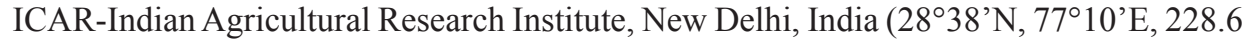
$m$ above mean sea level) during the winter (November-April) seasons of 2013-2014 and 2014-2015 on a sandy clay-loam soil (Typic Ustochrept). The mean annual rainfall of New Delhi is $650 \mathrm{~mm}$ and more than $80 \%$ generally occurs during the south-west monsoon season (July-September). The mean annual evaporation is $850 \mathrm{~mm}$. The soil of the experimental field had $147.3 \mathrm{~kg} \mathrm{ha}^{-1}$ alkaline permanganate oxidizable nitrogen $\mathrm{N}$ (Subbiah and Asija 1956), $13.7 \mathrm{~kg} \mathrm{ha}^{-1}$ available phosphorus (Olsen et al. 1954), $283.1 \mathrm{~kg} \mathrm{ha}^{-1}$ $1 \mathrm{~N}$ ammonium acetate exchangeable potassium (Hanway and Heidel 1952) and 0.53\% organic carbon (Walkley and Black 1934). The $\mathrm{pH}$ of soil was 7.7 (1:2.5 soil and water ratio; Prasad et al. 2006) and sulphate sulphur extracted with $0.15 \% \mathrm{CaCl}_{2} \cdot 2 \mathrm{H}_{2} \mathrm{O}$ and the soluble sulphate estimated turbidimetrically was $9 \mathrm{mg} \mathrm{kg}^{-1}$ of soil (Chesnin and Yien 1950).

\section{Experimental treatments, design and application of fertilizers}

Seven fertilizers treatments, viz. absolute control, prilled urea, 1.0\%, 2.0\%, 3.0\%, 4.0\% and $5.0 \%$ sulphur-coated urea were laid out in a randomized block design with three replications. The experimental field was disk-ploughed twice and levelled. Phosphorus and potassium at the rate of $26.2 \mathrm{~kg} \mathrm{P} \mathrm{ha}^{-1}$ as single super phosphate and $33.3 \mathrm{~kg} \mathrm{~K} \mathrm{ha}^{-1}$ as muriate of potash was broadcast at final ploughing and incorporated in soil. Nitrogen at the rate of $130 \mathrm{~kg} \mathrm{~N} \mathrm{ha}^{-1}$ as urea or sulphur-coated urea was applied in two equal splits; half 26 days after sowing (DAS) and the other half at maximum tillering (45 DAS). The amount of sulphur applied was 3.14, 6.28, 9.42, 12.56 and $15.70 \mathrm{~kg} \mathrm{ha}^{-1}$ with $1,2,3,4$ and 5\% SCU, respectively.

\section{Sowing and harvesting}

Wheat variety 'HD 2894' (also known as 'Pusa wheat 109') was sown with a seed drill at a spacing of $23 \mathrm{~cm} \times 5 \mathrm{~cm}$ in the third week of November, 2013 and 2014. This high yielding wheat variety was released for its commercial cultivation in 2008 from the Indian Agricultural Research Institute New Delhi, India by the state variety release committee. It is resistant to leaf rust disease and is also a non $1 \mathrm{~B} / 1 \mathrm{R}$ line and therefore has no sticky dough. The plot size was $6.0 \mathrm{~m} \times 3.0 \mathrm{~m}$ for each treatment. Irrigation channels measuring $1 \mathrm{~m}$ wide were placed between the replications. Wheat received five irrigations, each of 100-120 mm depth and was harvested in the second week of April, 2014 and 2015.

\section{Studies on growth and yield attributes of wheat}

Leaf area was measured by separating leaves from the stem, cleaning the leaves with deionized water and drying them with tissue paper. The area of fresh green leaves for each treatment was measured by using a leaf area meter (Model LICOR 3000, USA) and was 
expressed in $\mathrm{cm}^{2}$ plant $^{-1}$. Leaf area index (LAI) was calculated at the 105 days after sowing using the formula suggested by Evans (1972). The selected 10 spikes, which were used for spike length measurement, were also used to record the number of grains per spike was counted. The 1,000-filled grains, taken from sampled spikes, were first counted by a seed counter and then weighed to compute the 1,000-grain weight.

\section{Grain and straw yields of wheat}

Plants, excluding those from borders were harvested with sickles, tied in bundles and dried for 3-4 days to reduce the moisture content to around $12 \%$. After threshing, the seeds were cleaned and sun-dried, and seed and straw yields were recorded and expressed in tonnes $\mathrm{ha}^{-1}$ as given in the research manuscript. The harvest index was calculated by the formula given by Singh and Stoskopf (1971).

\section{Chemical analysis of plant samples}

Wheat plants cut at ground level at harvest from $50 \mathrm{~cm}$ row lengths were washed with tap water followed by dilute hydrochloric acid $(0.05 \mathrm{~N})$, demonized water and finally with double distilled water. The samples were dried in an oven at $65 \pm 5{ }^{\circ} \mathrm{C}$, separated into grain and straw, ground and sieved to pass 40-mesh sieve. Samples were analysed for total $\mathrm{N}$ using a Kjeldahl digestion unit as per procedures described by Prasad et al. (2006). Finally, the uptake of nitrogen was determined by multiplying dried wheat yields (grain and straw) and nitrogen concentration in the respective parts. Total nitrogen uptake was calculated by summing-up the two values, i.e. grain + straw uptake of nitrogen for rice.

\section{Nitrogen use-efficiencies}

In general, four terms are used in relation to nitrogen use-efficiency (NUE). These are: Agronomic Efficiency $\left(\mathrm{AE}_{\mathrm{N}}\right)$, Recovery Efficiency $\left(\mathrm{RE}_{\mathrm{N}}\right)$, Partial Factor Productivity of nitrogen $\left(\mathrm{PFP}_{\mathrm{N}}\right)$ and $\mathrm{N}$ harvest Index $\left(\mathrm{HI}_{\mathrm{N}}\right)$. The following expressions were used for determining these as suggested by Singh and Shivay (2003) and Shivay and Prasad (2012):
i) $\quad \mathrm{AE}_{\mathrm{N}}\left(\mathrm{kg}\right.$ grain increased $\mathrm{kg} \mathrm{N}^{-1}$ applied $) \frac{\mathrm{Yf}-\mathrm{Yc}}{\mathrm{Na}}$
ii) $\mathrm{RE}_{\mathrm{N}}(\%$ of $\mathrm{N}$ taken up by a crop)
$\frac{\mathrm{NUf}-\mathrm{NUc}}{\mathrm{Na}} \times 100$
iii) $\operatorname{PFP}_{\mathrm{N}}\left(\mathrm{kg}\right.$ grain $\mathrm{kg} \mathrm{N}^{-1}$ applied $)$
$\frac{\mathrm{Yf}}{\mathrm{Na}}$
iv) $\mathrm{HI}_{\mathrm{N}}$ (nitrogen harvest index as \%)
$\frac{\mathrm{NUg}}{\mathrm{NUg}+\mathrm{s}}$ 
In the above expressions, Yf and Yc are the yields $\left(\mathrm{kg} \mathrm{ha}^{-1}\right)$ in fertilized and control (no fertilizer) plots, respectively. NUf and NUc are the amounts of nitrogen taken up by a wheat crop in fertilized and control plots, respectively, and Na refers to the amount of nitrogen applied $\left(\mathrm{kg} \mathrm{ha}^{-1}\right)$. NUg and $\mathrm{NUg}+\mathrm{s}$ are the amounts of nitrogen uptake in wheat grain and grain + straw, respectively.

\section{Statistical analysis}

Mean data of two years were analysed using the F-test according to Gomez and Gomez (1984). Least significant difference (LSD) values at $P=0.05$ were used to determine the significance of differences between treatment means.

\section{Results}

\section{Growth characters and yield attributes}

Nitrogen application as uncoated prilled urea (PU) significantly increased plant height, LAI, spikes $\mathrm{m}^{-2}$, filled grains spike ${ }^{-1}$ and 1,000-grain weight in wheat over check (Table 1). SCU recorded higher values for most characters over PU and the highest values were obtained with 5\% SCU. As regards plant height, LAI, 3, 4 and 5\% SCUs were at par and significantly superior to 1 and $\%$ SCUs. Five per cent SCU produced significantly longer spikes than $4 \%$ SCU, which in turn produced longer spikes than 2 or $3 \%$ SCU, while $1 \%$ SCU was no better than uncoated PU. Five per cent SCU produced significantly more spikes $\mathrm{m}^{-2}$ than $1 \% \mathrm{SCU}$. Four and 5\% SCUs produced bolder wheat grains (higher 1,000 -grain weight) than 1,2 or $3 \%$ SCUs, which were at par.

Table 1. Effect of sulphur-coated urea on growth and yield attributes of wheat (mean of 2 years)

\begin{tabular}{|c|c|c|c|c|c|c|}
\hline Treatment & $\begin{array}{c}\text { LAI at } 105 \\
\text { DAS }\end{array}$ & $\begin{array}{l}\text { Plant height } \\
\text { at harvest } \\
(\mathrm{cm})\end{array}$ & $\begin{array}{l}\text { Spike length } \\
\quad(\mathrm{cm})\end{array}$ & $\begin{array}{l}\text { Spikes } \mathrm{m}^{-2} \\
\text { (Nos.) }\end{array}$ & $\begin{array}{c}\text { Filled grains } \\
\text { spike }^{-1} \text { (Nos.) }\end{array}$ & $\begin{array}{c}1,000 \text {-grain } \\
\text { weight }(\mathrm{g})\end{array}$ \\
\hline Absolute control & 3.06 & 81.6 & 7.3 & 271 & 37 & 37.1 \\
\hline Prilled urea & 3.97 & 91.7 & 8.8 & 375 & 51 & 39.3 \\
\hline $1.0 \%$ sulphur-coated urea & 4.13 & 93.0 & 9.0 & 390 & 53 & 39.8 \\
\hline $2.0 \%$ sulphur-coated urea & 4.56 & 94.3 & 9.2 & 395 & 55 & 40.2 \\
\hline $3.0 \%$ sulphur-coated urea & 4.73 & 95.1 & 9.5 & 406 & 57 & 40.8 \\
\hline $4.0 \%$ sulphur-coated urea & 4.80 & 95.8 & 9.7 & 412 & 60 & 41.4 \\
\hline $5.0 \%$ sulphur-coated urea & 4.85 & 96.3 & 10.1 & 422 & 63 & 42.3 \\
\hline $\operatorname{SEm} \pm$ & 0.051 & 1.09 & 0.13 & 4.5 & 1.3 & 0.62 \\
\hline $\operatorname{LSD}(\mathrm{P}=0.05)$ & 0.156 & 3.36 & 0.39 & 13.7 & 4.0 & 1.90 \\
\hline
\end{tabular}


Table 2. Effect of sulphur-coated urea on productivity and harvest index of wheat

\begin{tabular}{|l|c|c|c|}
\hline \multicolumn{1}{|c|}{ Treatment } & Grain yield (tonnes ha ${ }^{-1}$ ) & Straw yield (tonnes ha ${ }^{-1}$ ) & Harvest index (\%) \\
\hline Absolute control & 2.92 & 5.21 & 35.9 \\
\hline Prilled urea & 4.28 & 7.16 & 37.4 \\
\hline $1.0 \%$ sulphur-coated urea & 4.45 & 7.41 & 37.6 \\
\hline $2.0 \%$ sulphur-coated urea & 4.53 & 7.52 & 37.6 \\
\hline $3.0 \%$ sulphur-coated urea & 4.62 & 7.64 & 37.7 \\
\hline $4.0 \%$ sulphur-coated urea & 4.69 & 7.66 & 38.0 \\
\hline $5.0 \%$ sulphur-coated urea & 4.76 & 7.82 & 37.8 \\
\hline SEm \pm & 0.118 & 0.183 & 0.26 \\
\hline LSD $(\mathrm{P}=0.05)$ & 0.362 & 0.563 & 0.79 \\
\hline
\end{tabular}

\section{Grain and straw yield}

Nitrogen application as uncoated PU significantly increased grain and straw yield of wheat (Table 2). Four or 5\% SCU recorded significantly higher grain yield over 1, 2 and $3 \%$ SCU and uncoated PU. As regards, straw only 5\% SCU recorded a significant increase over 1, 2, 3 and 4\% SCU and uncoated PU. A significant increase in harvest index recorded with $\mathrm{N}$ application as uncoated $\mathrm{PU}$, there being no further significant increase with SCUs.

\section{Nitrogen concentration and uptake}

Application of $\mathrm{N}$ as uncoated PU significantly increased $\mathrm{N}$ concentration and uptake in wheat grain and straw as well as total $\mathrm{N}$ uptake by the wheat crop (grain + straw) (Table 3). Two to 5\% SCU were at a par and recorded significantly higher $\mathrm{N}$ concentration in grain than $1 \% \mathrm{SCU}$ or uncoated PU. As regards $\mathrm{N}$ uptake by straw, there was no significant increase due to SCU over uncoated PU. Three to 5\% SCU recorded significantly more $\mathrm{N}$ uptake by wheat grain and straw and total $\mathrm{N}$ uptake by wheat crop over 1 or $2 \%$ SCU and uncoated PU.

\section{Sulphur concentration and uptake}

Nitrogen application did not increase $\mathrm{S}$ concentration in wheat grain or straw, but $\mathrm{S}$ uptake by grain and straw and total $\mathrm{S}$ uptake by the wheat crop was increased, mainly due to increased yield (Table 4). A significant increase in S concentration in grain over uncoated PU was recorded only at a minimum of $4 \%$ coating with $\mathrm{S}$, while in the case of straw a significant increase was recorded even with $2 \%$ coating of $\mathrm{S}$. In the case of straw even uncoated PU recorded significantly higher S concentration over no nitrogen (control), showing that nitrogen application itself increased S uptake by wheat. The $5 \%$ SCU 
Table 3. Effect of sulphur-coated urea on nitrogen concentration in wheat grain, straw and its uptake by wheat crop (mean of 2 years)

\begin{tabular}{|l|c|c|c|c|c|}
\hline \multirow{2}{*}{\multicolumn{2}{|c|}{ Treatment }} & \multicolumn{2}{|c|}{ N concentration (\%) } & \multicolumn{3}{c|}{ N uptake $\left(\mathrm{kg} \mathrm{ha}^{-1}\right)$} \\
\cline { 2 - 6 } & Grain & Straw & Grain & Straw & Total \\
\hline Absolute control & 1.65 & 0.37 & 48.2 & 19.3 & 67.5 \\
\hline Prilled urea & 1.85 & 0.41 & 79.2 & 29.4 & 108.6 \\
\hline $1.0 \%$ sulphur-coated urea & 1.89 & 0.43 & 84.2 & 31.9 & 116.1 \\
\hline $2.0 \%$ sulphur-coated urea & 1.93 & 0.44 & 87.5 & 33.1 & 120.6 \\
\hline $3.0 \%$ sulphur-coated urea & 1.98 & 0.45 & 91.5 & 34.4 & 125.9 \\
\hline $4.0 \%$ sulphur-coated urea & 2.00 & 0.45 & 93.8 & 35.5 & 129.3 \\
\hline $5.0 \%$ sulphur-coated urea & 2.07 & 0.46 & 98.6 & 36.0 & 134.6 \\
\hline SEm \pm & 0.018 & 0.008 & 3.09 & 1.18 & 4.19 \\
\hline LSD $(\mathrm{P}=0.05)$ & 0.056 & 0.023 & 9.52 & 3.62 & 12.92 \\
\hline
\end{tabular}

Table 4. Effect of sulphur-coated urea on nitrogen use-efficiency and N: S ratio in wheat (mean of 2 years)

\begin{tabular}{|l|c|c|c|c|c|c|}
\hline \multicolumn{1}{|c|}{ Treatments } & $\begin{array}{c}\text { Partial factor } \\
\text { productivity } \\
\text { (kg grain } \mathrm{kg}^{-1} \\
\mathrm{~N} \text { applied) }\end{array}$ & $\begin{array}{c}\text { Crop } \\
\text { recovery } \\
\text { efficiency } \\
(\%)\end{array}$ & $\begin{array}{c}\text { Agronomic } \\
\text { efficiency } \\
(\mathrm{kg} \text { grain increased } \\
\left.\mathrm{kg}^{-1} \mathrm{~N} \text { applied }\right)\end{array}$ & $\begin{array}{c}\text { Nitrogen } \\
\text { harvest } \\
\text { index (\%) }\end{array}$ & $\begin{array}{c}\text { N:S ratio } \\
\text { in wheat } \\
\text { grain }\end{array}$ & $\begin{array}{c}\text { N:S ratio } \\
\text { in wheat } \\
\text { straw }\end{array}$ \\
\hline Absolute control & - & - & - & 71.5 & 9.18 & 1.85 \\
\hline Prilled urea & 32.9 & 31.6 & 10.5 & 72.9 & 9.75 & 1.86 \\
\hline $1 \%$ sulphur-coated urea & 34.2 & 37.4 & 11.8 & 72.6 & 9.96 & 7.87 \\
\hline 2\% sulphur-coated urea & 34.9 & 40.8 & 12.4 & 72.5 & 9.66 & 1.83 \\
\hline $3 \%$ sulphur-coated urea & 35.5 & 44.9 & 13.1 & 72.7 & 9.91 & 1.88 \\
\hline $4 \%$ sulphur-coated urea & 36.1 & 47.6 & 13.6 & 72.5 & 9.53 & 1.80 \\
\hline 5\% sulphur-coated urea & 36.6 & 51.6 & 14.2 & 73.3 & 9.42 & 1.77 \\
\hline SEm \pm & 0.97 & 1.28 & 0.69 & 0.28 & 0.21 & 0.020 \\
\hline LSD (P=0.05) & 3.07 & 4.04 & 2.19 & 0.87 & 0.65 & 0.060 \\
\hline
\end{tabular}

recorded the highest $\mathrm{S}$ concentration in wheat grain and straw and was at par with $4 \%$ SCU, but significantly superior to 1,2 and $3 \%$ SCU. As regards S uptake by grain and straw and total S uptake by wheat crop, even application of uncoated PU significantly increased it over control (no N). Five \% SCU was at par with 4\% SCU and recorded significantly higher $\mathrm{S}$ uptake by grain and straw and total $\mathrm{S}$ uptake by wheat crop.

\section{Utilization efficiency of nitrogen}

The 5\% SCU recorded the highest recovery efficiency $\left(\mathrm{RE}_{\mathrm{N}}\right)$ (Table 5), significantly higher than 3 or $4 \%$ SCU, which in turn recorded significantly more than 1 or $2 \%$ SCU. The 
Table 5. Effect of sulphur-coated urea on sulphur concentration in wheat grain, straw and its uptake by wheat crop (mean of 2 years)

\begin{tabular}{|c|c|c|c|c|c|}
\hline \multirow{2}{*}{ Treatment } & \multicolumn{2}{|c|}{ S concentration $(\%)$} & \multicolumn{3}{|c|}{ S uptake $\left(\mathrm{kg} \mathrm{ha}^{-1}\right)$} \\
\hline & Grain & Straw & Grain & Straw & Total \\
\hline Absolute control & 0.18 & 0.20 & 5.3 & 10.4 & 15.7 \\
\hline Prilled urea & 0.19 & 0.22 & 8.1 & 15.8 & 23.9 \\
\hline $1.0 \%$ sulphur-coated urea & 0.19 & 0.23 & 8.5 & 17.1 & 25.6 \\
\hline $2.0 \%$ sulphur-coated urea & 0.20 & 0.24 & 9.1 & 18.1 & 27.2 \\
\hline $3.0 \%$ sulphur-coated urea & 0.20 & 0.24 & 9.3 & 18.4 & 27.7 \\
\hline $4.0 \%$ sulphur-coated urea & 0.21 & 0.25 & 9.9 & 19.2 & 29.1 \\
\hline $5.0 \%$ sulphur-coated urea & 0.22 & 0.26 & 10.5 & 20.4 & 30.9 \\
\hline $\mathrm{SEm} \pm$ & 0.006 & 0.006 & 0.51 & 0.86 & 1.35 \\
\hline $\operatorname{LSD}(\mathrm{P}=0.05)$ & 0.019 & 0.019 & 1.56 & 2.64 & 4.14 \\
\hline
\end{tabular}

$\mathrm{RE}_{\mathrm{N}}$ increased from $31.6 \%$ with uncoated PU to $51.6 \%$ with $5 \% \mathrm{SCU}$, an increase of $63.3 \%$, which is fairly high. As regards agronomic efficiency $\left(\mathrm{AE}_{\mathrm{N}}\right), 3,4$ and $5 \% \mathrm{SCU}$ were at par and significantly superior to 1 or $2 \%$ SCU. A significant increase in partial factor productivity of nitrogen $\left(\mathrm{PFP}_{\mathrm{N}}\right)$ was observed only with 4 or $5 \% \mathrm{SCU}$. A significant decline in N:S ratio was observed only in straw when 5\% SCU recorded significantly less than uncoated PU and 1, and 3\% SCU (Table 4).

\section{Economics of sulphur-coated urea in wheat production}

Cost of sulphur-required or coating PU ranged from $6.28 \%$ of the cost of PU for $1 \%$ SCU to $31.43 \%$ for $5 \%$ SCU (Table S1). Thus, in 5\% SCU it could be nearly one third of the cost of PU. The total cost of coating PU with sulphur ranged from US \$ 3.42 for $1 \% \mathrm{SCU}$ to US \$ 10.15 for 5\% SCU per hectare for a nitrogen application of $130 \mathrm{~kg} \mathrm{~N} \mathrm{ha}^{-1}$. Data on economics of SCU showed that significant increase in net return was obtained only when $4 \% \mathrm{~S}$ was coated onto PU, there being no significant increase when $\mathrm{S}$ coating was increased to $5 \%$ (Table S2). However, a significant benefit: cost ratio was obtained only with $5 \% \mathrm{~S}$ coating onto PU. Thus 5\% SCU was a better choice.

\section{Discussion}

Response of wheat to nitrogen is in accord with several such reports available in literature (Gentry et al. 1989; Howarth et al. 2002; Ladha et al. 2005; Tilman et al. 2011). Similarly response to $\mathrm{S}$ fertilization has been reported by a number of researchers (Mishra et al. 2001; Singh 2001; Biswas et al. 2004). The main objective of the present study was to evaluate SCU with graded levels of sulphur coatings as a source of S as well as their effect on nitrogen use efficiency. No such report is available, since most of the earlier studies 
involved SCUs with a fixed S coating only. For this reason we prepared 1, 2, 3, 4 and 5\% $\mathrm{S}$ coated SCU in our own research laboratory.

Higher nitrogen use efficiency with SCU over PU obtained in the present study is in accord with reports from earlier researchers (Prasad et al. 1971; Prasad and Prasad 1980; Bijay-Singh and Katyal 1987). This could be due to slow release of N from SCU (Reddy and Prasad 1975) and therefore reduced N losses (Prasad and Rajale 1972; Prakasa Rao and Prasad 1980). This study also brought out that $\mathrm{N}$ application increases $\mathrm{S}$ uptake by wheat. A positive $\mathrm{N} \times \mathrm{S}$ interaction in wheat has been reported (Randall et al. 1981; Mishra et al. 2001). These results also support the contention that heavy application of nitrogen without $\mathrm{S}$ application has depleted soils of native $\mathrm{S}$ in intensive cropping systems, such as rice-wheat in Asia (Prasad 1996).

We planned and conducted this study because elemental sulphur is fairly costly in India and other developing countries, which do not have sulphur deposits and most of it has to be imported. The present study brings out that from the viewpoint of a source of sulphur as well as from the viewpoint of nitrogen use efficiency, $4 \%$ to $5 \% \mathrm{~S}$ coating onto

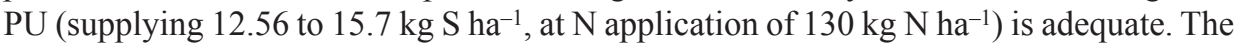
general recommendation for cereals in different countries is $10-40 \mathrm{~kg} \mathrm{~S}^{-1}$ (Morris 2007) and 5\% SCU will meet the need in most situations. In the present study 5\% SCU supplied $50 \%$ of the sulphur needs of the wheat crop and increased recovery efficiency by $60.3 \%$ over PU. The economics of 5\% SCU is fairly sound and therefore it will be readily acceptable to the farmers. In earlier studies SCU was evaluated mainly as an enhanced efficiency of nitrogen fertilizer and its economics did not work out sound enough to encourage its use by small holdings farmers. Continued use of 5\% SCU in intensive cerealcereal cropping systems, such as rice-wheat, will assure regular supply of sulphur and can decrease sulphur deficiency in soil.

SCU should be promoted as a source of S as well as an enhanced efficiency of nitrogen fertilizer. The present study suggests that 5\% coating of sulphur onto prilled urea is adequate for wheat production. Also, in long run it will have environmental benefits by reducing the nitrogen losses since it increased the nitrogen recovery efficiency.

\section{Acknowledgements}

The authors duly acknowledge the partial financial support received from the Matix Fertilisers and Chemicals Limited (MFCL), Mumbai, Maharashtra, India. Our sincere thanks are due to Director, Joint Director Research and Head, Division of Agronomy, Indian Agricultural Research Institute, New Delhi for their advice and support.

\section{References}

Bijay-Singh, Katyal, J.C. 1987. Relative efficiency of some new urea-base nitrogen fertilizers for growing wetland rice on permeable soils. J. Agric. Sci. Cambridge 109:27-31.

Biswas, B.C., Sarkar, M.C., Tanwar, S.P.S., Das, S., Kalwe, S.P. 2004. Sulphur deficiency in soils and crop responses to fertilizer sulphur in India. Fert. News 49(10):13-33. 
Chesnin, L., Yien, C.H. 1950. Turbidimetric determination of available sulphates. Soil Sci. Soc. American Proc. 15:149-151.

Dick, W.A., Kost, D., Chen, L. 2008. In: Jezed, J. (ed.), Sulphur: A Missing Link between Soils, Crops and Nutrition. Am. Soc. of Agron. Madison, WI, USA. pp. 59-82.

Evans, G.C. 1972. Quantitative Analysis of Growth. Blackwell Scientific Publication Oxford. London, UK.

Flinn, J.C., Marmaril, C.P., Valseo, L.E., Kaiser, K. 1984. Efficiency of modified urea fertilizers for tropical agriculture. Fert. Res. 13:209-221.

Gentry, L.E., Wang, X.T., Below, F.E. 1989. Nutrient uptake by wheat seedlings that differ in response to mixed nitrogen nutrition. J. Plant Nutr. 12:363-373.

Gomez, K.A., Gomez, A.A. 1984. Statistical Procedures for Agricultural Research, 2nd edn. Wiley. New York, USA.

Hanway, J.J., Heidel, H. 1952. Soil analysis methods as used in Iowa State College Soil Testing Laboratory. Bulletin 57. Iowa State College of Agriculture. Ames, IA, USA. 131 p.

Hocking, P.J., Pinkerton, A., Good, A. 1996. Recovery of field grown canola from sulphur deficiency. Aust. J. Exp. Agric. 36:79-85.

Howarth, R.W., Boyer, E.W., Pabich, W.J., Galloway, J.M. 2002. Nitrogen use in the United States from 1961-2000 and future potential needs. Ambio. 31:88-96.

Ladha, J.K., Pathak, H., Kruprik, T.J., Six, J., Van Kessel, C. 2005. Efficiency of fertilizer nitrogen in cereal production: Retrospect and prospects. Adv. Agron. 87:85-156.

Malkouti, H.J., Bazbordi, A., Lotfalahi, M., Shahabii, A.A., Slavoshi, K., Vakil, R., Ghadari, J., Keshavarz, M.H., Ghazemzadeh, M., Ghanberpouri, R., Dashadi, M., Babakari, M., Zaynalifard, M. 2008. Comparison of complete and sulphur coated urea fertilizers with pre-plant urea in increasing grain yield and nitrogen use efficiency in wheat. J. Agric. Sci. Tech. 10:173-183.

McLachlan, K.D. 1975. Sulphur in Australian Agriculture. University Press. Sydney, Australia.

Meena, H.N., Shivay, Y.S. 2010. Productivity of short-duration summer forage crops and their effect on succeeding aromatic rice in conjunction with gypsum-enriched urea. Indian J. Agron. 55:11-15.

Messick, D.L. 2003. Sulphur fertilizers - A global perspective. In: Sarkar, M.C., Biswas, B.C., Das, S. Kalwe, S.P., Maity, S.K. (eds), Proc. TSI/FAI/IFA Workshop on Sulphur in Balanced Fertilization. The Fertilizer Association of India. New Delhi, India. pp. 1-7.

Mishra, J., Mishra, P.H., Pandey, I.P. 2001. Nitrogen and sulphur nutrition of wheat crop. I. Growth and yield. Ann. Plant Soil Res. 3:84-88.

Mitchell, C.C., Mullins, G.L. 1990. Sources, rate and time of sulphur application to wheat. Sulphur Agric. 14:20-24.

Morris, R.J. 2007. Sulfur in agriculture - international perspective. In: Tewatia, R.K., Choudhary, R.S., Kalwe, S.P. (eds), Proc. TSI/FAI/IFA Workshop on Sulphur in Balanced Fertilization. The Fertilizer Association of India. New Delhi, India. pp. 1-7.

Olsen, R., Cole, C.V., Watanabe, F.S., Dean, L.A. 1954. Estimation of available phosphorus in soil by extraction with sodium carbonate. USDA. Circular 939. Washington, DC, USA.

Oo, N.M.L., Shivay, Y.S., Kumar, D. 2007. Effect of nitrogen and sulphur fertilization on yield attributes, productivity and nutrient uptake of aromatic rice (Oryza sativa). Indian J. Agric. Sci. 77:772-775.

Prakasa Rao, E.V.S.P., Prasad, R. 1980. Nitrogen leaching losses from conventional and new nitrogen fertilizers in lowland rice culture. Plant Soil 57:383-392.

Prasad, M., Prasad, R. 1980. Yield and nitrogen uptake of rice as affected by variety and methods of planting and new fertilizers. Fert. Res. 1:207-213.

Prasad, R., Rajale, G.B., Lakhdive, B.A. 1971. Nitrification retarders and slow-release nitrogen fertilizers. Adv. Agron. 23:337-383.

Prasad, R., Rajale, G.B. 1972. The influence of nitrification inhibitors and slow-release N materials on transformation of fertilizer $\mathrm{N}$ in soils of fluctuating moisture. Soil Biol. Bioch. 4:451-457.

Prasad, R. 1996. Nitrogen use efficiency. In: Tandon, H.L.S. (ed.), Nitrogen Research and Crop Production. Fertilizer Development and Consultation Organization. New Delhi, India. pp. 104-115.

Prasad, R. 2005. Rice-wheat cropping systems. Adv. Agron. 86:255-339. 
Prasad, R., Shivay, Y.S., Kumar, D., Sharma, S.N. 2006. Learning by Doing Exercise in Soil Fertility - A practical manual for soil fertility. Division of Agronomy, IARI. New Delhi, India.

Prasad, R. 2007. Crop Nutrition-Principles and Practices. New Vishal Publications. New Delhi, India. 272 p.

Prasad, R. 2013. Fertilizer nitrogen, food security, health and the environment. Proc. Indian Nat. Sci. Acad. Part B 79:997-1010.

Randall, P.J., Spencer, K., Freney, J.R. 1981. Sulphur and nitrogen effects on wheat. I. Concentration of sulfur and nitrogen and the N:S ratio in grain in relation to the yield response. Aust. J. Agric. Res. 32:302-312.

Rashid, M., Bajwa, M.I., Hussain, R., Naeemuddin, M., Rahman, F. 1992. Rice response to sulphur in Pakistan. Sulphur Agric. 16:3-5.

Raun, W.R., Barreto, H.J. 1992. Maize grain yield response to sulphur fertilization in Central America. Sulphur Agric. 16:26-29.

Reddy, R.N.S., Prasad, R. 1975. Studies on the mineralization of urea, coated urea and nitrification inhibitor treated urea in the soil. J. Soil Sci. 26:304-312.

Shivay, Y.S., Prasad, R. 2012. Zinc-coated urea improves productivity and quality of Basmati rice (Oryza sativa L.) under zinc stress condition. J. Plant Nutr. 35:928-951.

Shivay, Y.S., Kumar, D., Prasad, R., Pal, M. 2014. Effect of cosavet fertis WG and bentonite sulphur pellets on growth, yield attributes, productivity and sulfur use efficiency in Basmati rice. Indian J. Fert. 10(7):32-38.

Singh, I.D., Stoskopf, N.C. 1971. Harvest index in cereals. Agron. J. 63:224-226.

Singh, M.V. 2001. Importance of sulphur in balanced fertilizer use in India. Fert. News 46(10):13-18.

Singh, S., Shivay, Y.S. 2003. Coating of prilled urea with ecofriendly neem (Azadirachta indica A. Juss) formulations for efficient nitrogen use in hybrid rice. Acta Agron. Hungarica 51:53-59.

Subbiah, B.V., Asija, G.L. 1956. A rapid procedure for assessment of available nitrogen in rice soils. Curr. Sci. 25:259-260.

Tilman, D., Blazer, C., Hill, J., Befort, B.J. 2011. Global food demand and the sustainable intensification of agriculture. Proc. Natl. Acad. Sci. USA 108:20260-20264.

Trenkel, M. 1997. Controlled-release and Stabilized Fertilizers in Agriculture. Fertilizer Industry Association. Paris, France. 151 p.

Walkley, A.J., Black, I.A. 1934. An examination of the Degtjareff method for determination of soil organic matter and a proposed modification of the chronic acid titration method. Soil Sci. 37:29-38.

\section{Electronic Supplementary Material (ESM)}

Electronic Supplementary Material (ESM) associated with this article can be found at the website of CRC at http://www.akademiai.com/content/120427/

Electronic Supplementary Table S1. Input prices for sulphur-coated urea used in cultivation of wheat (mean of 2 years)

Electronic Supplementary Table S2. Economics of sulphur-coated urea and prilled urea on wheat production (mean of 2 years) 